\title{
Tobacco package health warnings: a global success story
}

\author{
Rob Cunningham
}

Canadian Cancer Society, Ottawa, Ontario, Canada

\section{Correspondence to}

Rob Cunningham, Canadian Cancer Society, Ottawa, ON K1P 5G3, Canada;

Rob.Cunningham@cancer.ca

Check for updates

(c) Author(s) (or their employer(s)) 2022. No commercial re-use. See rights and permissions. Published by BMJ.

To cite: Cunningham R. Tob Control

2022;31:272-283.

\section{INTRODUCTION}

Thirty years ago, in 1992, the largest cigarette package health warnings in the world had a size of just $20 \%$ of the package front and back. Those warnings, in Canada, were text-only messages in package colours that appeared at the bottom of the front and back surfaces. Over time, warnings have become much larger and the use of graphic pictures has become widespread (figures 1-4). The WHO Framework Convention on Tobacco Control (FCTC), ${ }^{1}$ together with the FCTC implementation guidelines for packaging and labelling, ${ }^{2}$ has been a key driver of success. ${ }^{3-6}$

That warnings can be impactful at decreasing sales has been underlined over decades by the tobacco industry's fierce lobbying against more effective warnings and by the commencement of legal challenges. ${ }^{378}$ Warnings have passed the 'scream test'. Tobacco industry opposition has sought to block, delay, weaken and overturn warning requirements.

Well-designed warnings decrease tobacco use and increase awareness of the health effects, ${ }^{2}$ and are an effective government response to the underawareness and underappreciation of the vast range of health consequences and their magnitude. ${ }^{29} 10$ This is especially the case given that most tobacco consumers begin as adolescents younger than the legal age, when they have even less awareness. Packaging has promotional value, ${ }^{11-15}$ and larger graphic warnings reduce the package's promotional impact and denormalise the product.

The evidence in support of the effectiveness of well-designed warnings, including the incremental effectiveness of larger warnings, and picturebased warnings instead of text-only warnings, was supported with evidence in Canada ${ }^{16-20}$ and has long been overwhelming and has increased over time. ${ }^{81021-36}$ In a sense, research has proved the obvious. Health concerns are a key reason for quitting or considering quitting, ${ }^{37-39}$ and warnings provide health information. Indeed, if better warnings did not work, then why has the tobacco industry been so strongly opposed?

This paper aims to provide a historical overview of package warning developments, particularly over the last 30 years; to outline the role of the FCTC; to identify tobacco industry strategies and arguments that have been overcome; to identify other labelling issues; and to outline why tobacco package health warnings have seen such global success.

\section{EARLY DEVELOPMENTS}

Package health warnings first appeared in the 1960s and 1970s on a legislated or voluntary basis, beginning with the USA in $1966 .{ }^{3}$ Warnings were initially located on the lateral side of cigarette packages, with a single warning using weak general language, with no mention of cancer, heart attacks or other specific health effects. In 1973, Australia required a warning on the front of the package, but with small text that could be in package colours. ${ }^{7}$ In 1977, Sweden required 16 rotated messages, with information on specific health effects, to appear in about $20 \%$ of the front or back using black on white or other dark on light colour ${ }^{40} 41$; this lasted until 1993 when Sweden implemented European Union (EU) 4\% text warnings. ${ }^{42}$ In 1993, Thailand required 10 rotated text warnings covering $25 \%$ of the package front and back. ${ }^{43}$ In 1994, Canada required eight rotated black and white text warnings in about the top $35 \%$ of the package front/ back. $^{45} 46$

By 1996, there were at least 127 countries/jurisdictions with legislated or voluntary warnings. ${ }^{47} 48$ Although a large proportion of these countries still had a single weak warning, more and more were strengthening requirements. ${ }^{47-49}$

\section{THE IMPACT OF THE FCTC}

When negotiations for the FCTC began in October 2000, only Canada had required warnings with graphic pictures, and had required a size of at least $50 \%$ of the package front/back. ${ }^{50}$ When the FCTC was approved in May 2003, Brazil was the only other country to require picture warnings or to have at least a 50\% size on average (Brazil had 0\% front, $100 \%$ back). ${ }^{51}$

The FCTC, with 182 Parties as of September 2021, includes in Article 11 mandatory minimum requirements for Parties: warnings must be at least $30 \%$ - and should be $50 \%$ or more-of the principal display areas, which for cigarettes is the package front and back; pictures may be used; there must be rotated messages, rather than a single unchanging message; messages can include non-health messages; warnings must be in the language(s) of the country; the requirements apply to all categories of tobacco products. The FCTC itself recognises the fundamental importance of health warnings, with the FCTC's very first guiding principle stating in part, 'Every person should be informed of the health consequences, addictive nature and mortal threat posed by tobacco consumption and exposure to tobacco smoke'. ${ }^{2}$

FCTC Guidelines for implementation of Article 11 on packaging and labelling (FCTC Guidelines), adopted in 2008, recognise "that the effectiveness of health warnings and messages increases with 


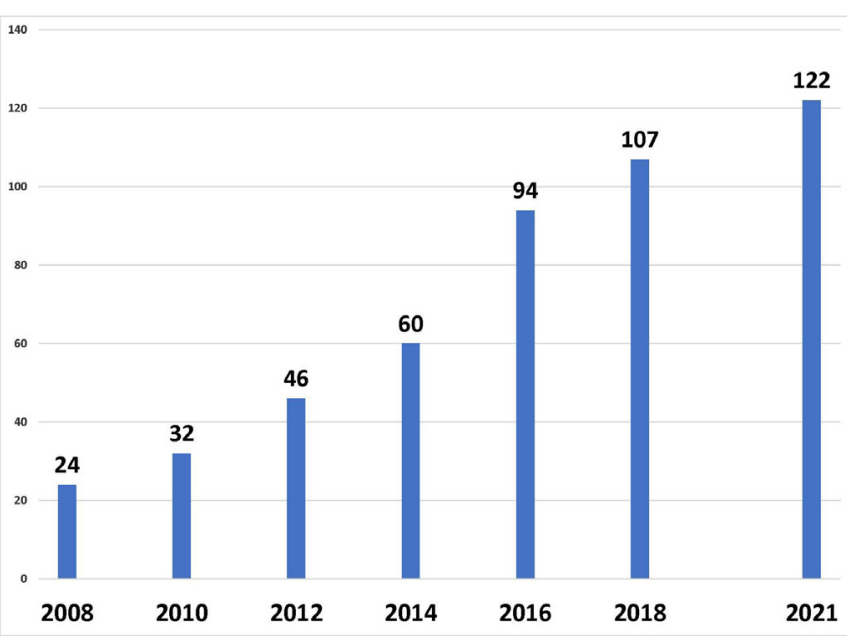

Figure 1 Number of countries/jurisdictions requiring warnings of $50 \%$ or more (on average) of the front and back of cigarette packages. ${ }^{50}$

their size' and that Parties should 'aim to cover as much of the principal display areas as possible'. ${ }^{2}$ The FCTC Guidelines also recognise that warnings 'that contain both pictures and text are far more effective than those that are text-only' and 'have the added benefit of potentially reaching people with low levels of literacy and those who cannot read the language(s)' of text-only warnings. ${ }^{2}$

The FCTC Guidelines, which represent an international consensus, recognise that 'well-designed health warnings and messages on tobacco product packages have been shown to be a cost-effective means to increase public awareness of the health effects of tobacco use and to be effective in reducing tobacco consumption'. This authoritatively counters industry misinformation that better warnings have no incremental impact.

In developing package warning provisions in the FCTC and later the FCTC Guidelines, governments had decades of experience in drafting warning requirements, observing industry strategies to undermine warnings and responding to these strategies. Non-government organisations, also with decades of experience, advocated for effective FCTC warning provisions. ${ }^{52-54}$

The FCTC has helped to further revolutionise warning requirements internationally, with countries continuing a decades-long

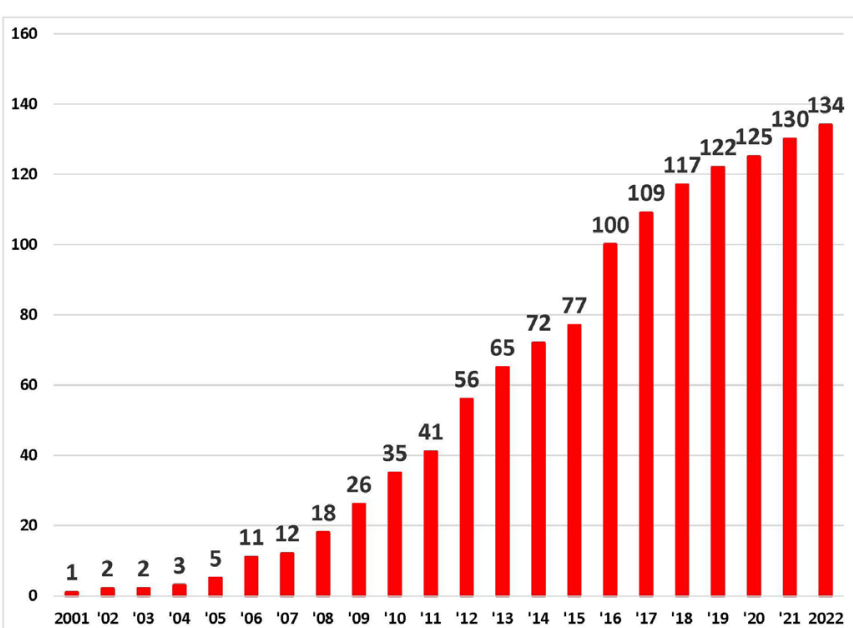

Figure 2 Number of countries/jurisdictions requiring picture warnings on cigarette packages. ${ }^{50}$ approach of improving on each other. The FCTC has added fuel to a spiral of upward government competition.

By at least 2008, in many countries Philip Morris International (PMI) was, in the absence of legislated warnings, voluntarily placing 30\% text warnings in national languages on the package front/back, including in Africa, thus discouraging countries from legislating beyond FCTC minimum standards ${ }^{55}$ (figure 3).

\section{SIZE AND LOCATION OF WARNINGS}

The size of warnings now being achieved in many countries was inconceivable 30 years ago. By October 2021, there were at least 122 countries/jurisdictions requiring warnings of $50 \%$ or more (on average) of the package front/back (figure 1); 27 had required at least $70 \%$, and 10 had required at least $85 \% .^{5056}$ The world leaders in warning size are:

- 92.5\% Timor-Leste $(85 \%, 100 \%) .{ }^{57}$

- 92.5\% Turkey (85\%, 100\%).

- 90\% Maldives (90\%, 90\%).

- 90\% Nepal (90\%, 90\%).

- 90\% Vanuatu (90\%, 90\%).

- 90\% Benin (90\%, 90\%), 2022

- $87.5 \%$ New Zealand (75\%, 100\%).

Box 1 outlines how the world's largest health warnings have increased over time. Despite the progress, there remain at least 49 countries not meeting the FCTC 30\% minimum, with most of these having no warning requirement at all to appear on the front/back. ${ }^{50} 56$

Countries are increasingly requiring that warnings be placed at the top of front and back surfaces, and requiring that pictures be located on both the front and back. Further, more countries are requiring health warnings to appear on more sides in addition to the front/back. For example, the EU requires 'Smoking kills' or 'Smoking kills—quit now' to appear on 50\% of a lateral side. Several countries require a series of rotated black on yellow text warnings on a lateral side, while Thailand requires these on both lateral sides (figure 5). ${ }^{58}$ Timor-Leste (figure 3 ) and Nepal require warnings/messages to appear on five of six sides.

A more recent trend has been for countries to require a minimum surface area for warnings, in addition to a minimum percentage size (eg, EU, Australia, New Zealand). For 20 cigarettes, the largest minimum warning surface area for the front and back is $46.5 \mathrm{~cm}^{2}$ in the Canadian province of Quebec (figure 4), followed by Canada at $43.6 \mathrm{~cm}^{2} .50$ (The surface area for the front and back of flip-top packages of 20 standard-length $(\sim 83-84 \mathrm{~mm})$ cigarettes is typically about $49 \mathrm{~cm}^{2}$, though this can vary. Canada requires cigarettes, effective February 2022, to be sold in the slide and shell package format, ${ }^{59}$ which increases surface area compared with flip top (figure 4)). A minimum package width can have the effect in part to prevent the narrow superslims 'purse' pack formats (figure 4). Comoros $\left(30.0 \mathrm{~cm}^{2}\right)$ and India $\left(14.0 \mathrm{~cm}^{2}\right)$ apply the minimum warning surface area to all tobacco products, including smokeless tobacco and bidis.

\section{USE OF PICTURES}

A picture says a thousand words. That simple adage helps explain why, as of October 2021, there are at least 134 countries/jurisdictions that have finalised requirements for picture warnings (figure 2). ${ }^{50}$ Of the 20 most populous countries in the world, only four have not yet implemented picture warnings: China (though Hong Kong and Macau have pictures); USA (implementation pending); Japan; and Democratic Republic of the Congo. 


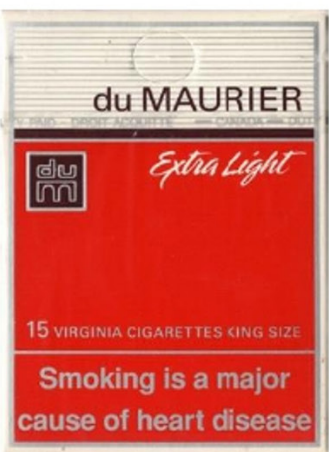

Canada 1989

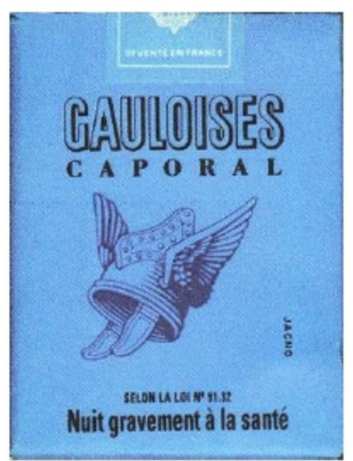

France (EU) c. 1993 (A)
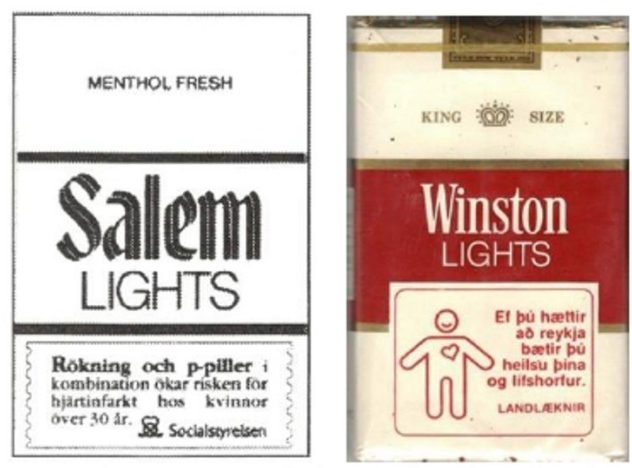

(B) Iceland, 1991 (C)

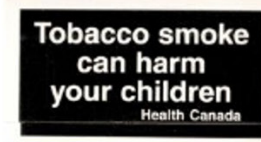

dU MAURIER

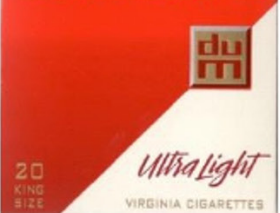

Canada 1994
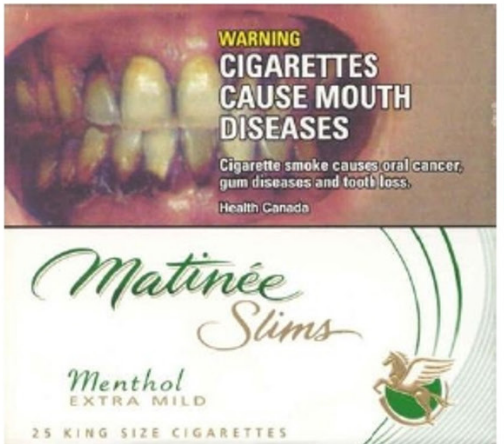

Canada, 2001

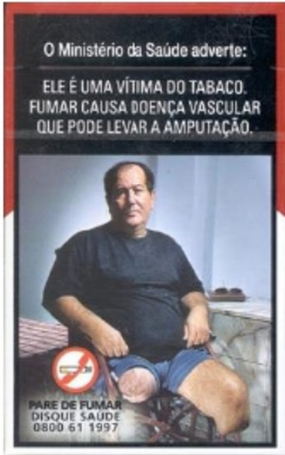

Brazil (back), 2008

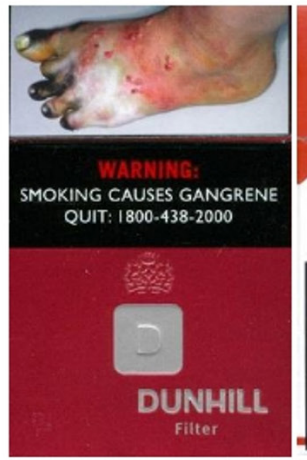

Singapore 2009

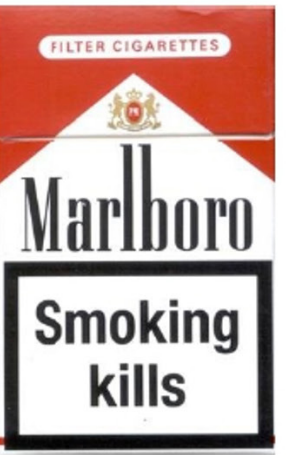

UK (EU) 2004 (front)

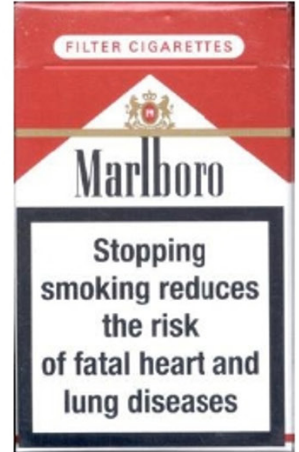

UK (EU) 2004 (back)

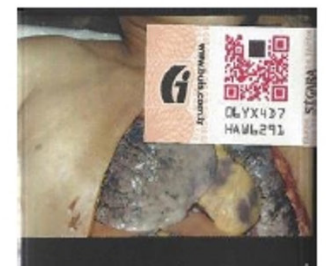

Sigara içmek

ölümcül akciğer

kanserine neden olur.

ALO 171 Sigara Bırakma Dan șma Hatt

20 sigara

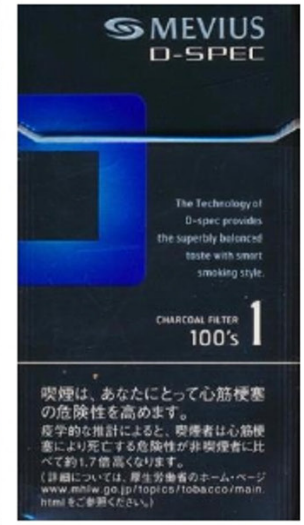

Turkey, back 2021 Japan 2009

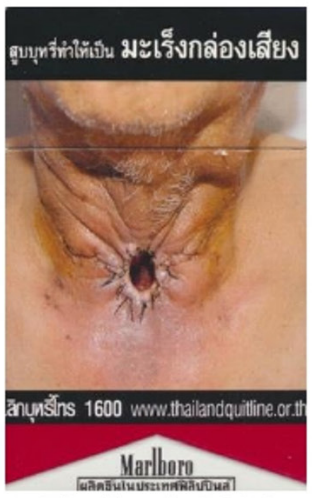

Thailand, 2014

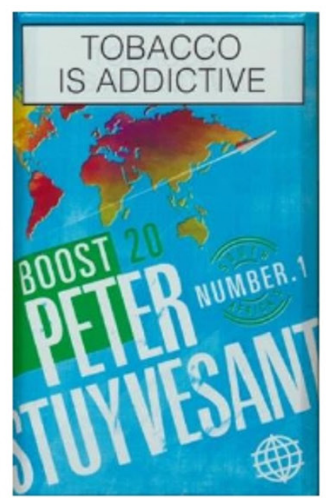

South Africa 2018

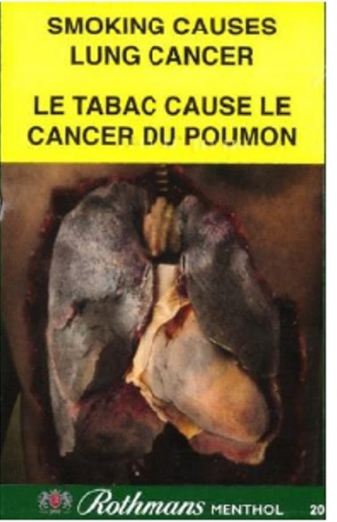

Vanuatu, 2018

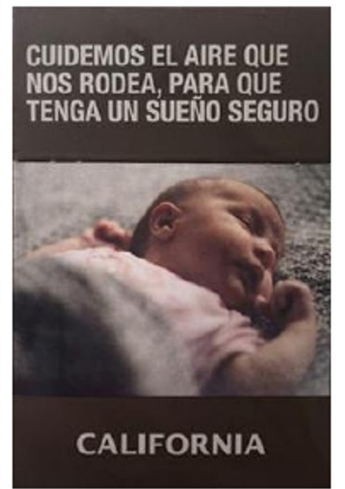

Uruguay, 2021

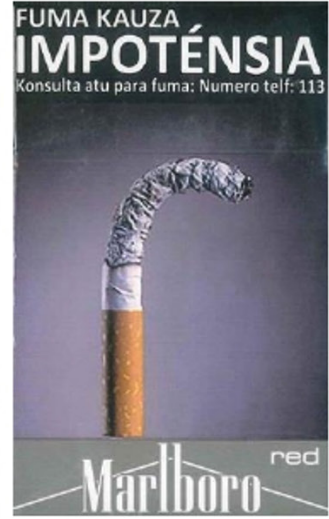

Timor-Leste, 2018, including package top, bottom

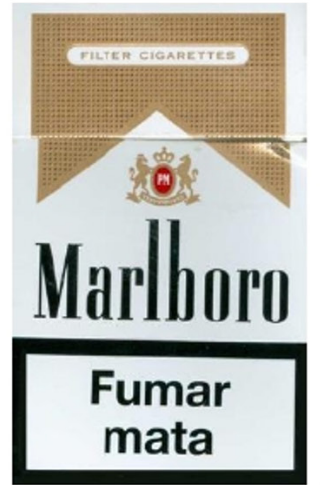

Angola, 2008 (D)

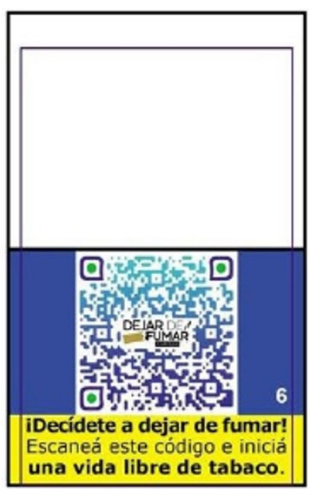

Costa Rica, 2022

Figure 3 Examples of tobacco package health warnings and labelling. (A) Pursuant to a 1989 Directive, the EU required text warnings of 4\% in unilingual countries. (B) Sweden required text warnings of this type, 1977-1993. (C) Iceland required a rotated series of pictogram warnings, which appeared on the package back, with each pictogram in a different single colour. (D) PMI voluntarily placed this $30 \%$ text warning, "Smoking kills", in Angola. 


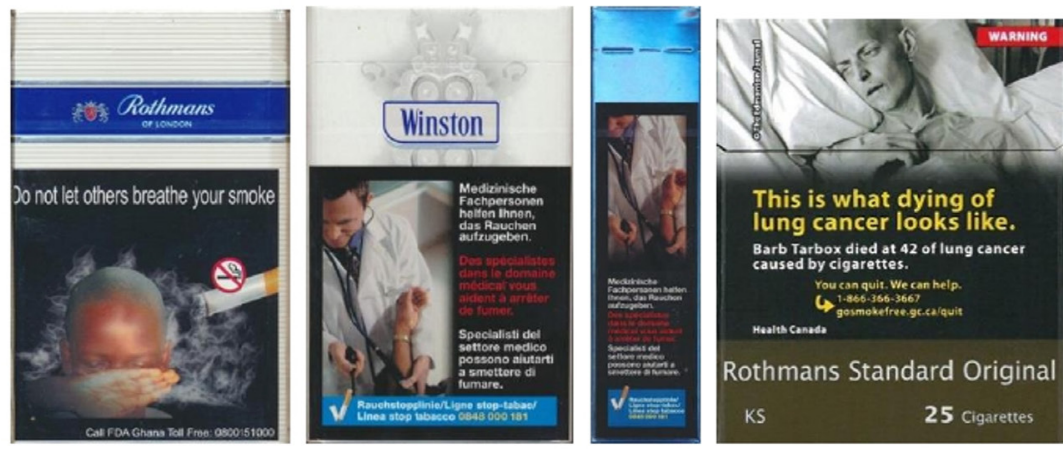

Ghana 2018

Switzerland, 2012 \& 2013 (A) Canada, 2020, flip top

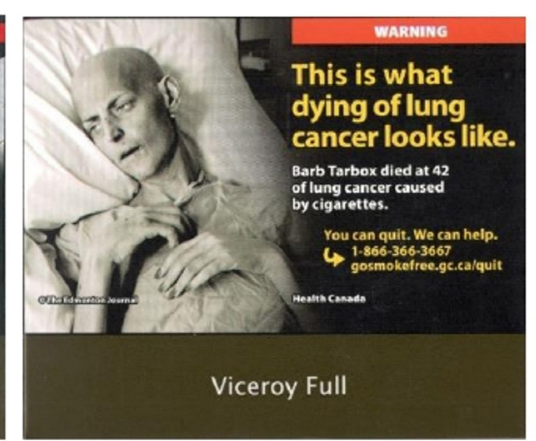

Canada 2020, slide and shell (B)
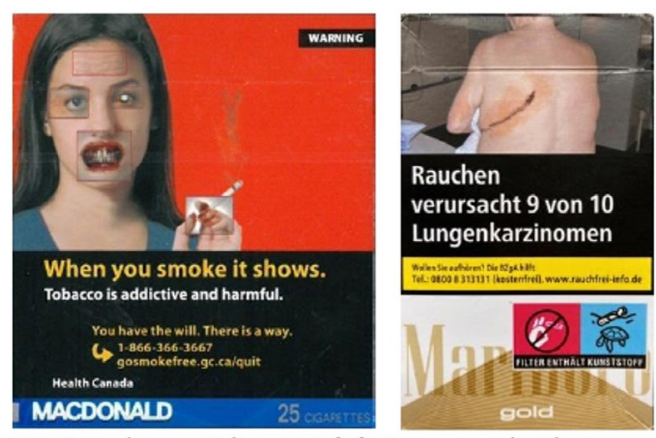

Quebec (Canada), 2016 (C) Germany (EU), 2021 (D)

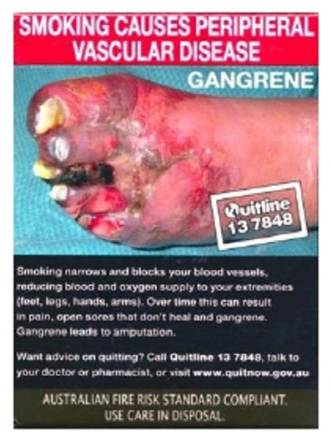

Australia, 2012

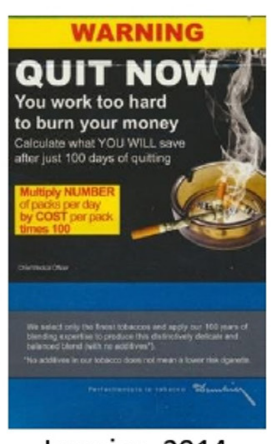

Jamaica, 2014

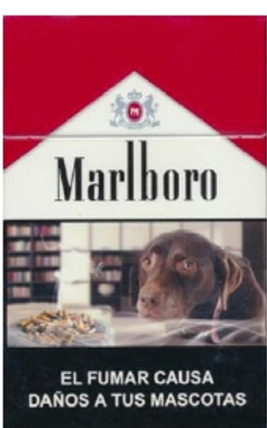

Panama 2018

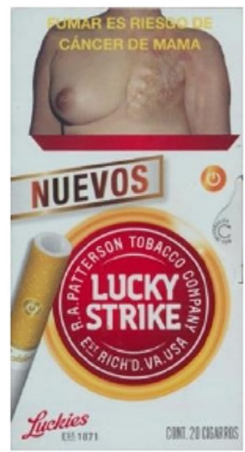

Mexico, 2018

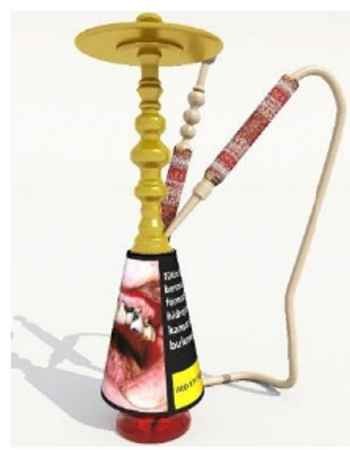

Turkey (E)

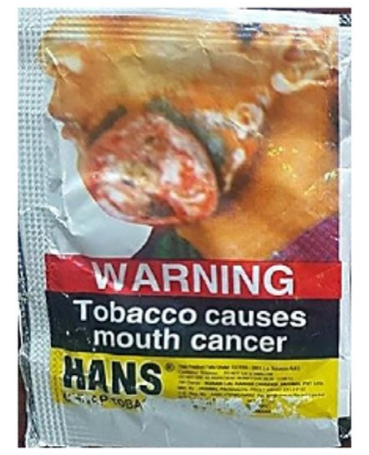

India, smokeless tobacco, 2016

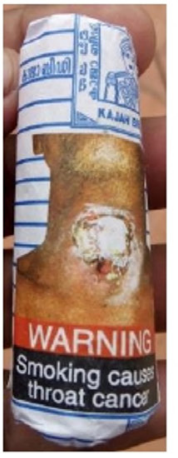

India, bidis, 2016

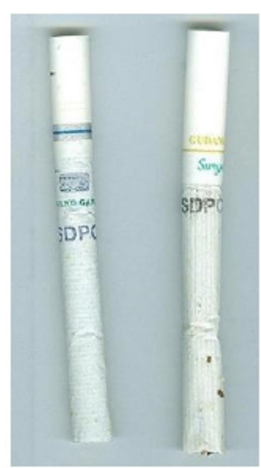

Singapore, 2010 (J)

Figure 4 Additional examples of tobacco package health warnings and labelling. (A) Two Switzerland packages with 20 cigarettes with same warning shown, with one Vogue Superslims 100mm. (B) All Canadian cigarette packages are required to be slide and shell format as of 7 Feb 2022 , which increases warning surface area. The two Canadian packages shown each have 25 cigarettes. (C) Though Canada requires a $75 \%$ warning size, Quebec (Canadian province) requires a minimum warning surface area of $46.5 \mathrm{~cm} 2$, which increases the size to $93 \%$ on this $75 \mathrm{~mm}$ high package. (D) This row includes messages on plastic in filters and the environment (Germany/EU, 6\%), fire risk (Australia, 10\%), saving money by quitting (Jamaica), and secondhand smoke and pets (Panama). (E) Example of Turkey's required warning on waterpipe bottles in restaurants/cafes, but this is not enforced. (F) Singapore tax marking on cigarettes, "SDPC" (Singapore Duty Paid Cigarettes).

Warnings with graphic pictures were first implemented in Canada in $2001 .^{60-62}$ At the time, the industry argued in part that it was technically impossible to print colour pictures on packages in Canada. ${ }^{63}$ The industry repeated this argument in Brazil and other countries proposing picture warnings earlier on ${ }^{85}$ with the argument only abandoned when lacking any credibility as more and more countries required pictures. The industry itself has used pictures on packages for promotional purposes. ${ }^{66-68}$

Earlier, Iceland had required one-colour pictogram warnings (figure 3), which appeared on the package back, from 1985 to 1996 , after which EU 4\% text warnings were implemented. $^{341}$

\section{WARNING CONTENT AND ROTATION}

Global experience has seen a wide variety of content for warnings, including messages for dozens of different health effects. Many messages are needed because of the number of health effects and because different messages are applicable to, and resonate with, different people. A country's overall warning system should effectively convey the health risks and their magnitude.

Pictures can present vivid, unavoidable images of health harms. Evidence supports very graphic, hard-hitting picture warnings as effective at discouraging smoking, increasing impact, including for risk perceptions and quit intentions. ${ }^{1069-73}$ 
Box 1 Evolution of world's largest cigarette package health warnings.

This outlines the historical evolution of the countries requiring the largest cigarette health warnings in the world, identifying chronologically when a country had become the new world leader with the largest size. ${ }^{50}$ The listing is based on the average size for the package front and back. The percentages in parentheses indicate the required size on the front and on the back.

$20 \%$ Canada, 1989 (20\% front, 20\% back). ${ }^{46}$

$25 \%$ Thailand, $1993(25 \%, 25 \%) .{ }^{434}$

29\% Australia, 1995 (25\%, 33\%).

$30 \%$ Poland, $1998 .^{190}$

$35 \%$ Canada, 1994 (including border). ${ }^{45} 46$

$50 \%$ Canada, 2001 (50\%, 50\%). ${ }^{60-62}$

56\% Belgium, 2003 (including border). *

$60 \%$ Australia, $2006(30 \%, 90 \%) .{ }^{191}$

$65 \%$ Mauritius, June $2009(60 \%, 70 \%){ }^{192}$

$80 \%$ Uruguay, November 2009 (80\%, 80\%).

$82.5 \%$ Australia, 2012 (75\%, 90\%).

$85 \%$ Thailand, $2014(85 \%, 85 \%) .{ }^{44}$

$90 \%$ Nepal, $2015(90 \%, 90 \%) .^{118}$

$92.5 \%$ Timor-Leste, 2018 (85\%, 100\%). ${ }^{57}$

*Warning size including the border surrounding the warning varied somewhat based on package format.

By the late 1990s, PMI said it would defer to health authorities regarding warning content, but for picture warnings in 2000 PMI took the position that the Canadian warnings were 'using full color "shock images" designed to disparage the product and to make the products' packaging repulsive. The label is not about information but denigration' ${ }^{74}$ PMI would later object to warnings in Brazil on the grounds that they were too shocking, ${ }^{75} 76$ a further sign of effectiveness.

Complementing warnings having strong graphic images with messages that support cessation, such as pack inserts providing cessation tips, could aid quitting-related responses. ${ }^{77-81}$ Many countries have warnings that include toll-free quitline numbers, which can lead to a substantial increase in calls. ${ }^{82-89}$ Many warnings also include a website address. Costa Rica requires a large QR code on the package back (figure 3).

In determining warning content, messages used in other countries can be assessed for potential use. Messages can target different subpopulations (eg, youth, male/female). Further, warnings can support other tobacco control measures. For example, secondhand smoke warnings can support smoking bans in public places. Messages on the cost of buying cigarettes complement higher tobacco taxes given that such messages can remind/emphasise to consumers how much is actually being paid (eg, per year).

Some countries have required non-health messages, such as money saved by quitting (Ecuador, Jamaica, Saint Lucia, Trinidad and Tobago, Argentina, EU, ${ }^{90}$ Djibouti $^{91}$ ); compliance with ignition propensity regulations ('Australian fire risk standard compliant. Use care in disposal', Australia ${ }^{92}$ ); secondhand smoke and pets (Panama); cigarette butts and ocean pollution (Argentina); and plastic in filters and the environment $(\mathrm{EU})^{93}$ (figures 4 and 5).

The number of rotated messages appearing concurrently has not exceeded 16, which Canada has done since 2001, though some countries have additional messages on a lateral side or side other than front/back, and Canada has interior messages. The EU has three sets of 14 warnings changed annually, and in the 1990s had two on the front and a choice of up to 15 on the back. ${ }^{90}$ Australia and New Zealand have had two sets of seven messages changed annually, with some other countries also having multiple sets. Pakistan, India, Myanmar and Iran are examples where only one picture warning has appeared at a time, though changing periodically.

For most countries, warnings are not refreshed frequently enough, which leads to wear out and reduced impact over time. ${ }^{389495}$ Some countries, such as Australia and Canada, have gone a decade in between changing warning requirements. However, some countries have had nine or more rounds of picture warnings, including Ecuador, Colombia, Mexico, Panama and Uruguay. ${ }^{50}$ Countries should have a continuous warning system such that a next set of warnings is always ready or in preparation. Having a large number of warning messages appearing concurrently, and continuously and frequently changing the required set of messages (at least annually), are necessary to inform consumers of the extensive array of health effects and to reduce wear out. Additional approaches to reduce wear out and attract consumer attention can include varying design elements and using prominent colours for the text portion of warnings.

\section{INDUSTRY UNDERMINING OF WARNINGS}

Over decades, the tobacco industry has undermined warnings in many ways, including by having a voluntary warning to deter stronger regulation; having voluntary warnings in a foreign language (English); using weak message content; minimising warning size, prominence and visibility including through the choice of colours and package location; having deficient print quality for colour images; having warnings stretch over bevelled edges; and marketing 'slims' packages and various novel package formats, which impair warnings. ${ }^{3} 896-99$

\section{INDUSTRY ARGUMENTS}

In opposing strengthened warnings, the industry has used many arguments, including: existing warnings (sometimes voluntary warnings) are adequate; it is not proven that better warnings would be more effective; people already know the health effects; smokers would be 'demonized' and treated like outcasts; it would cost the industry too much; governments wanting these messages should pay for mass media advertising; it would infringe on the ability to adequately brand the product; the requirements would be legally invalid; there would be increased contraband. ${ }^{8} 65100-102$ The industry has argued that large warnings infringe intellectual property protection in the World Trade Organization and other international trade agreements, but with the upholding of Australia's plain packaging ${ }^{103}$ this cannot be a valid argument. Governments have been able to overcome all these arguments. As to contraband, prominent warnings unique to a country in national language(s) actually make it easier to identify illegal product.

\section{INDUSTRY LEGAL CHALLENGES}

The tobacco industry has threatened and commenced legal challenges as a means to deter and overturn more effective package warnings. Arguments have varied but have included: freedom of expression; the regulation not being authorised by the enabling statute; countries subject to EU requirements cannot have more stringent provisions; expropriation/infringement of trademarks/ brands/intellectual property rights; and infringement of a trade agreement(s). Overwhelmingly, legal challenges have been 

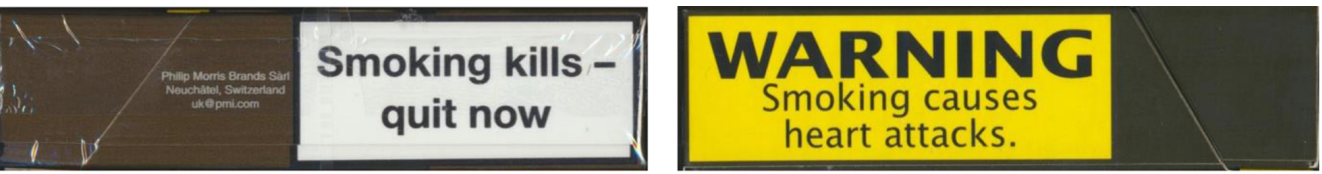

New Zealand, 2018

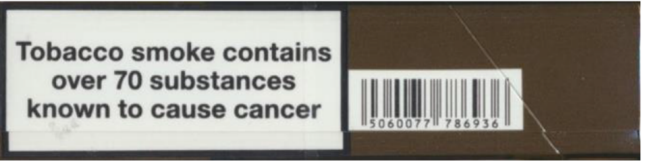

EU (UK) 2018, left and right lateral sides

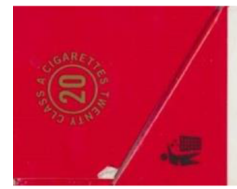

Smoke from this product contains extremely
addictive nicotine and toxic substances
such as Tar and Carbon Monoxide.
No safe level of consumption exists for this
product.
Chief Medical officer

Jamaica, 2014

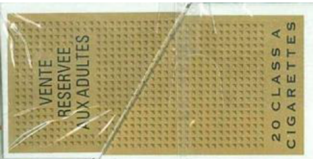

Cesser de fumer c'est Epargner votre argent!

Djibouti, 2009 ("Quitting smoking is saving your money")

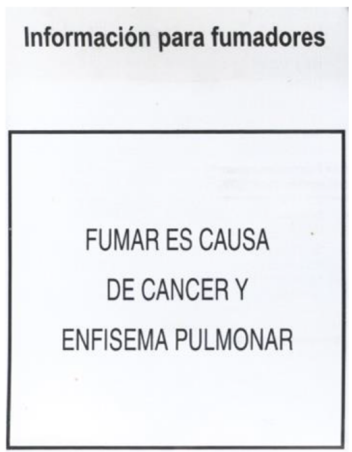

Mexico, 2006,

front of onsert

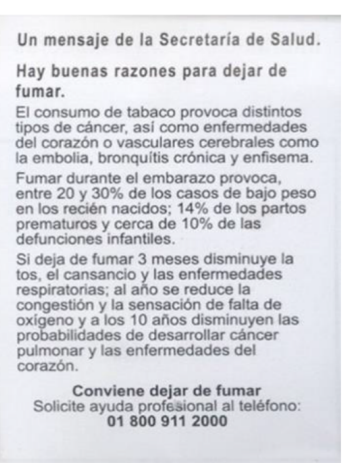

Mexico, 2006,

Back of onsert

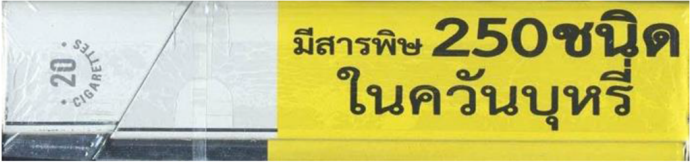

Thailand, 2015, (messages on both lateral sides).

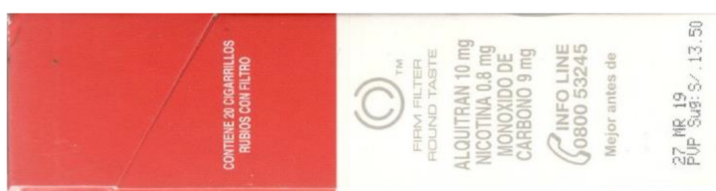

Peru, 2018, with quantitative yield numbers

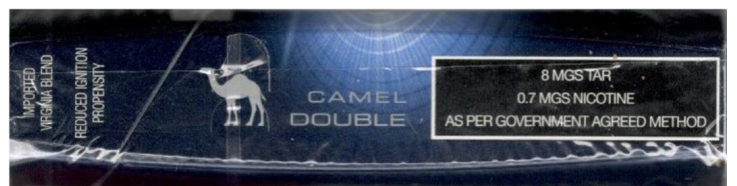

South Africa, 2018, with quantitative yield numbers

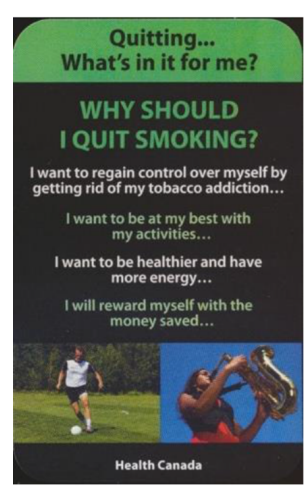

Canada, 2012, insert

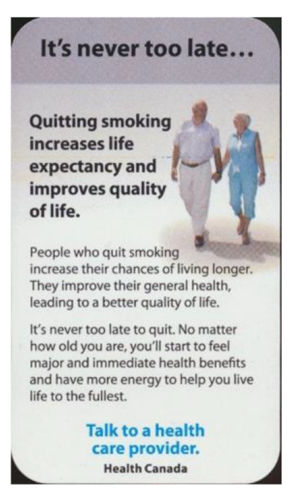

Canada, 2012, insert

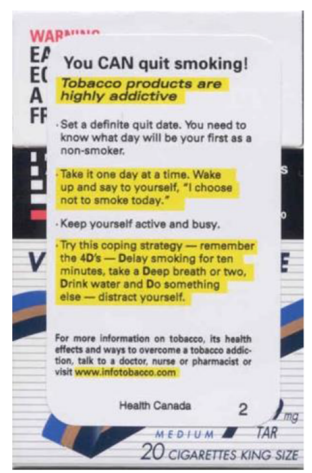

Canada, 2001, insert with size relative to package

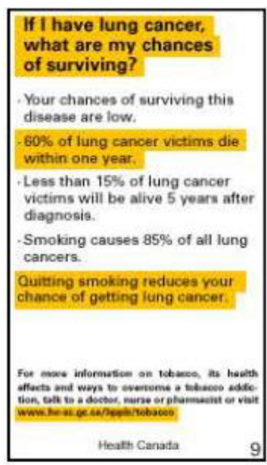

Canada, 2001, insert

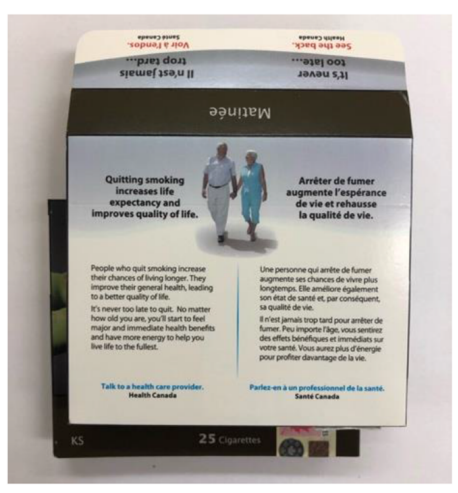

Canada, 2021, interior message, slide and shell package (A)

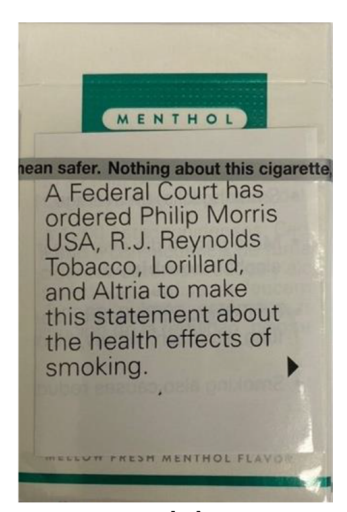

US onsert (B)

Figure 5 Examples of messages appearing on inserts, onserts and lateral sides of cigarette packages. (A) The Canadian inserts in flip-top packages in the 2001 and 2012 rounds were required to be visible when the package was opened. The inserts were bilingual, English on one side, French on the other. Interior messages were also required for packages in slide and shell format. With the new 2022 Canadian mandatory requirement for the slide and shell format, interior messages will thus only appear on the slide. (B) A US onsert appearing 2018-2020. The onsert was under the cellophane and glued to the back of the package. The package could be opened without removing the onsert (by using the tear tape to remove the top part of the cellophane). The onsert would open to have eight panels, four on each side, with English on one side (four panels) and the cover, and Spanish text (three panels) on the other. 
dismissed, including in the UK (6\% text, larger than EU 4\%), ${ }^{104}$ Germany (text warnings), ${ }^{105} \mathrm{EU}$ (text $30 \%$ front, $40 \%$ back, 2002; 65\% pictures, 2016), ${ }^{106-108}$ Philippines (25\% text), ${ }^{109} 110$ Canada (50\% pictures), ${ }^{111-113}$ Uruguay (80\% pictures), ${ }^{114} 115$ Indonesia (40\% pictures), ${ }^{116} 117 \mathrm{Nepal}$ (75\% pictures), ${ }^{118}$ Thailand (85\% pictures) ${ }^{119}$ Sri Lanka (80\% pictures), ${ }^{120}$ Brazil (pictures, $100 \%$ one side), ${ }^{65}{ }^{76}$ Kenya (pictures, 30\% front, $50 \%$ back), ${ }^{121-123}$ India (85\% pictures) $)^{108} 124125$ and Uganda $(65 \%$ pictures), ${ }^{126}$ among others.

However, US courts have held that while 50\% picture warnings could be justified, the specific pictures adopted in 2011 and the requirement to depict the quitline number 1-800-QUIT-NOW were invalidated (2012). ${ }^{127-129}$ The USA adopted new 50\% pictures in 2020, followed by new industry litigation still in progress. In Paraguay, ${ }^{130}$ Philippines ${ }^{131}$ and Turkey, ${ }^{132}$ warnings were invalidated for administrative reasons, but these countries each successfully responded with replacement picture warning requirements.

\section{TOXIC EMISSION MESSAGES AND MISLEADING DESCRIPTORS}

While in the past many countries required tar, nicotine and sometimes carbon monoxide yield numbers on packages, usually appearing on a lateral side, FCTC Guidelines recommend against this because of the misleading nature of these yields. ${ }^{2} 133$ Instead, many countries now require qualitative toxic emission messages with no quantitative emission indications (figure 5). At the same time, a 2021 analysis of laws of 129 countries/jurisdictions found 38 still requiring tar/nicotine yield numbers on packages. $^{134}$

Separate from a legislated requirement for emission yield numbers on packages, at least 58 countries have, as the FCTC Guidelines recommend, ${ }^{2}$ banned companies from being able on their own to place yield numbers on packages. ${ }^{56}$

Beginning with Brazil in 2001, ${ }^{135} 136$ at least 137 countries/ jurisdictions specifically prohibit 'light' and/or 'mild' descriptors for at least cigarettes, ${ }^{56}$ and often other specific terms, because of their misleading nature, as outlined in FCTC Guidelines. ${ }^{2} 137$ Among examples of jurisdictions banning specific descriptors beyond 'light' and 'mild', the EU has banned 'low-tar', 'ultralight', 'natural', 'organic', 'without additives', 'without flavours' and 'slim'138 ; Canada bans reference to a colour or a filter characteristic. $^{59} 139$

\section{INSERTS}

One country, Canada, has required package inserts, with eight rotated messages, initially required in 2001-2012 with 16 rotated messages (figure 5). In Israel, 2019 legislation includes regulatory authority to require inserts, ${ }^{140}$ and a working group has been established to develop insert content. In Mexico for a period, by a 2004 voluntary agreement, onserts appeared outside $25 \%$ of packages under the cellophane (figure 5 ). ${ }^{141}$ In the USA intermittently over a 24-month period during 2018-2020, five onserts with corrective health messaging appeared pursuant to a court order (figure 5). ${ }^{142} 143$ Inserts can provide additional information on health effects as well as cessation information.

\section{PLAIN PACKAGING}

Plain packaging, which in itself makes tobacco products less appealing and discourages tobacco use, also complements and enhances the effectiveness of package warnings. In this issue, Moodie et al provide an overview of the critical importance of plain packaging. ${ }^{144}$ At least 21 jurisdictions have finalised plain packaging requirements as of October $2021,{ }^{50}$ though some do not apply plain packaging to all tobacco products.

\section{SINGLE PRESENTATION REQUIREMENT}

One country, Uruguay in 2008, has adopted a single presentation requirement, such that there can only be one brand variation sold per brand family. Thus, for Marlboro there can be only one of Marlboro 'Red', 'Gold', 'Silver' or Menthol, etc, thereby curtailing brand variant names and package colours creating deceptive impressions. ${ }^{145-149}$ Industry legal challenges to the Uruguay requirement were dismissed. ${ }^{114} 150$

\section{WARNINGS ON CIGARETTES THEMSELVES}

Research indicates that warnings directly on cigarette sticks have tremendous potential and would be an effective measure to discourage smoking and increase quitting. ${ }^{151-162}$ A health warning would be there for every puff of every cigarette. Though included in FCTC Guidelines, ${ }^{2}$ no country has yet required a warning on the cigarette itself. Canada consulted on the measure in 2018, ${ }^{163-165}$ and a private member's bill was introduced in the UK Parliament in 2021. ${ }^{166}$ Singapore has required a tax-paid marking on cigarettes since 2009 (figure 4). ${ }^{167} 168$

\section{SMOKELESS TOBACCO}

Smokeless tobacco has substantial consumption rates in some countries. By 2020, at least 47 countries required picture warnings for smokeless tobacco, 42 of which required a size of at least 50\%. ${ }^{56}{ }^{169}$ Smaller package sizes can represent an issue in developing warnings.

\section{WATERPIPE TOBACCO}

Waterpipe smoking is popular in certain countries, and with specific population groups in some other countries. ${ }^{170}$ Some studies have considered warning options for the device itself in addition to packaging. ${ }^{171-175}$ Turkey has required a rotated series of health warnings to be displayed on waterpipe devices in public settings such as cafes/restaurants ${ }^{176-178}$ (figure 4), but this has not been enforced. Nigerian regulations include health warnings on waterpipe devices, but compliance levels have not been confirmed. ${ }^{179}$

\section{ELECTRONIC CIGARETTES AND NOVEL PRODUCTS}

Going forward an issue for countries is to determine appropriate health messages for newer product categories such as electronic cigarettes, heated tobacco products and nicotine pouches. Determining appropriate messages for longer standing product categories may also apply, such as smokeless tobacco and waterpipe tobacco, which in some markets may be newer. The FCTC Guidelines recommend that governments consider health messages appropriate for the particular tobacco product category. $^{2}$

\section{WHY WARNINGS HAVE BEEN A SUCCESSFUL MEASURE}

There are a series of reasons why the global movement to larger, picture-based, more impactful warnings has been so successful. Of note, the cost is paid by industry, not government, which is especially attractive for low and middle-income countries. The measure is effective and has broad national reach, reaching every tobacco consumer many times per day, as well as family, friends and coworkers of the consumer. The measure is simple to understand, permanent and can be modified/enhanced over time. Warnings can be politically attractive and announced by 
health ministers, which itself generates media coverage and public awareness of health effects.

From a regulatory perspective, countries already have experience with package warnings, better warnings are a logical next step and there is an absence of credible arguments against. Countries also have access to resources and international cooperation to make things even easier, including websites providing information and describing international practices, ${ }^{180-184}$ technical assistance in drafting laws ${ }^{185}$ and other countries willing to license pictures for free. For tobacco companies, they normally have tremendous difficulty in mobilising others to oppose better warnings.

Finally, there is substantial international pressure to enact warnings. Governments do not want to be left behind regionally/internationally. An industry trade journal referred in 2010 to "countries vying to outdo each other... "Mine is bigger than yours" is the motto'. ${ }^{186}$ Countries are publicly scrutinised, including through global summary reports, ${ }^{5056187} 188$ and the FCTC reporting process. ${ }^{189}$ The WHO has actively supported better warnings, including through WHO regional and country offices, while non-government organisations have been effective in advocacy for better warnings, in country after country.

\section{LOOKING TO THE FUTURE}

Despite the tremendous progress achieved, no country has yet come close to implementing a full, comprehensive and necessary tobacco health warning system. Countries need to, and will, improve through larger sizes; standardising package format and increasing warning surface area; increased use of the package exterior (such as requiring messages on five of six cigarette package sides); improved rotation both in terms of increasing the number of messages appearing concurrently and the frequency with which sets of warnings change; inserts/interior messages with both health warning and cessation content; innovative and enhanced message content, including newly covered health effects (eg, diabetes, cleft palate) and non-health messages, as well as new attention-getting means of conveying messages; messages directly on cigarettes/products themselves; and complementary implementation of plain packaging.

\section{CONCLUSION}

The history of tobacco package health warnings, already an enormous accomplishment, is just beginning. Package warning and labelling requirements reach all tobacco consumers, 24 hours/day, 365 days/year, and are a well-established, evidencebased, low cost and highly effective means at reducing tobacco use. Government recognition of this can only increase. Though clearly not all tobacco consumers will quit because of warnings, package health warnings are, and will remain, a crucial and permanent tool for successful tobacco control. The best is yet to come.

Acknowledgements I would like to thank Emily Mullins, MPH, for helpful assistance in the preparation of the final manuscript, and Michael Chaiton, PhD, for helpful comments on a draft manuscript.

Contributors The author conceived, wrote and edited the paper.

Funding The author has not declared a specific grant for this research from any funding agency in the public, commercial or not-for-profit sectors.

Competing interests None declared.

Patient consent for publication Not required.

Provenance and peer review Commissioned; externally peer reviewed.

ORCID iD

Rob Cunningham http://orcid.org/0000-0003-2219-2384

\section{REFERENCES}

1 WHO Framework Convention on Tobacco Control, 2003. Available: https://apps. who. int/iris/rest/bitstreams/50793/retrieve [Accessed 18 Jul 2021].

2 Conference of the Parties to the WHO Framework Convention on Tobacco Control. Guidelines for Implementation of Article 11 of the WHO Framework Convention on Tobacco Control (Packaging and Labelling of Tobacco Products), 2008. Available: https://www.who.int/fctc/guidelines/article_11.pdf [Accessed 18 Jul 2021].

3 Hiilamo H, Crosbie E, Glantz SA. The evolution of health warning labels on cigarette packs: the role of precedents, and tobacco industry strategies to block diffusion. Tob Control 2014;23:e2.

4 Hiilamo H, Glantz SA. Implementation of effective cigarette health warning labels among low and middle income countries: state capacity, path-dependency and tobacco industry activity. Soc Sci Med 2015;124:241-5.

5 Sanders-Jackson AN, Song AV, Hiilamo H, et al. Effect of the Framework Convention on Tobacco Control and voluntary industry health warning labels on passage of mandated cigarette warning labels from 1965 to 2012: transition probability and event history analyses. Am J Public Health 2013:103:2041-7.

6 Chung-Hall J, Craig L, Gravely S, et al. Impact of the WHO FCTC over the first decade: a global evidence review prepared for the Impact Assessment Expert Group. Tob Control 2019;28:s119-28.

7 Chapman S, Carter S. "Avoid health warnings on all tobacco products for just as long as we can": a history of Australian tobacco industry efforts to avoid, delay and dilute health warnings on cigarettes. Tob Control 2003;12:iii13-iii22.

8 Hammond D, Tan YL, Dorotheo U. Simplifying the WHO FCTC article 11 guidelines: evidence based best practices. Bangkok, Thailand: Southeast Asia Tobacco Control Alliance, 2010. Available: https://seatca.org/dmdocuments/Article11.pdf [Accessed $18 \mathrm{Jul} 2021]$.

9 World Bank. Curbing the epidemic: governments and the economics of tobacco control, 1999. Available: https://documents1.worldbank.org/curated/en/ 914041468176678949/pdf/multi-page.pdf [Accessed 18 Jul 2021].

10 Hammond D. Health warning messages on tobacco products: a review. Tob Control 2011:20:327-37.

11 Wakefield M, Morley C, Horan JK, et al. The cigarette pack as image: new evidence from tobacco industry documents. Tob Control 2002;11 Suppl 1:i73-80.

12 Pollay R. The Role of Packaging Seen Through Industry Documents. Expert report prepared for: JTI-Macdonald, Imperial Tobacco Canada Ltd and Rothmans, Benson \& Hedges Inc. v. Attorney General of Canada and Canadian Cancer Society (Intervenor). Supreme Court, Province of Quebec, District of Montreal. Defense Exhibit D-116, 2001.

13 Slade J. The pack as advertisement. Tob Control 1997;6:169-70.

14 Moodie C, Hastings G. Tobacco packaging as promotion. Tob Control 2010;19:168-70.

15 Trimble DG, Yu L, Welding K, et al. Analysis of wedding appeals on cigarette packs in China. Tob Control 2021. doi:10.1136/tobaccocontrol-2020-056189. [Epub ahead of print: 09 Apr 2021].

16 Environics Research Group Ltd. Reactions to cigarette packaging formats (prepared for Canadian Cancer Society/Physicians for a Smoke-Free Canada), Focus Canada 1998-4, 1999

17 Environics Research Group. Qualitative (focus group) report regarding health warning labels and images on cigarette packages (prepared for Health Canada), 1999.

18 Environics Research Group. Canadian adult and youth opinions on the sizing of health warning messages (prepared for Health Canada), 1999.

19 Canadian Cancer Society. Compilation of selected evidence regarding the impact of tobacco package warnings and labelling: a submission to Members of Parliament for use during consideration of regulations under the Tobacco Act (6 volumes 208 tabs), 2000.

20 Environics Research Group. Evaluation of new warnings on cigarette packages (prepared for Canadian Cancer Society), 2001

21 Hammond D. FCTC article 11 fact sheet. Health warning messages on packs. International Union Against Tuberculosis and Lung Disease and University of Waterloo, 2007. Available: https://www.fctc.org/wp-content/uploads/2008/11/COP3_Article_11_Fact_Sheet_Health_warnings.pdf [Accessed 18 Jul 2021].

22 Cunningham R. Gruesome photos on cigarette packages reduce tobacco use. Bull World Health Organ 2009;87:569.

23 Fong GT, Hammond D, Hitchman SC. The impact of pictures on the effectiveness of tobacco warnings. Bull World Health Organ 2009;87:640-3.

24 Reddy KS, Arora M. Pictorial health warnings are a must for effective tobacco control. Indian J Med Res 2009;129:468-71.

25 Hammond D. Tobacco labelling and packaging toolkit. A guide to FCTC article 11, 2009. Available: https://tobaccolabels.s3.ca-central-1.amazonaws.com/uploads/ 2013/12/IUATLD-Tookit-Complete-Mar-3-2009.pdf [Accessed 18 Jul 2021].

26 World Health Organization. Showing the truth, saving lives: the case for pictorial health warnings. World No Tobacco Day 31 May 2009, 2009. Available: https:// www.paho.org/hq/dmdocuments/2009/brochureEnglishversion.pdf [Accessed 18 Jul 2021]. 
27 Canadian Cancer Society. Compilation of evidence regarding the impact of tobacco package warnings and labelling: a submission to Members of Parliament for use during consideration of regulations under the Tobacco Act: Tobacco Products Labelling Regulations (Cigarettes and Little Cigars); Promotion of Tobacco Products and Accessories Regulations (Prohibited Terms); Regulations Amending the Tobacco Products Information Regulations (5 volumes, 156 tabs), 2011.

28 Institute for Global Tobacco Control. State of evidence review: health warning labels on tobacco products. Baltimore, MD: Johns Hopkins Bloomberg School of Public Health, 2013. Available: https://www.globaltobaccocontrol.org/sites/default/files/ HealthWarnings_state_of_evidence_final_11_18_2013_web_0.pdf [Accessed 18 Jul 2021].

29 Campaign for Tobacco-Free Kids. Health warning labels: evidence on pictorial warnings, 2016. Available: https://www.tobaccofreekids.org/assets/global/pdfs/en/ WL_evidence_en.pdf [Accessed 18 Jul 2021].

30 Noar SM, Francis DB, Bridges C, et al. The impact of strengthening cigarette pack warnings: systematic review of longitudinal observational studies. Soc Sci Med 2016;164:118-29.

31 Noar SM, Hall MG, Francis DB, et al. Pictorial cigarette pack warnings: a metaanalysis of experimental studies. Tob Control 2016;25:341-54.

32 Noar SM, Francis DB, Bridges C, et al. Effects of strengthening cigarette pack warnings on attention and message processing: a systematic review. Journal Mass Commun Q 2017;94:416-42.

33 Ratih SP, Susanna D. Perceived effectiveness of pictorial health warnings on changes in smoking behaviour in Asia: a literature review. BMC Public Health 2018;18:1165.

34 Francis DB, Mason N, Ross JC, et al. Impact of tobacco-pack pictorial warnings on youth and young adults: a systematic review of experimental studies. Tob Induc Dis 2019;17:41.

35 Kaai SC, Sansone G, Meng G, et al. Quasi-experimental evaluation of Kenya's pictorial health warnings versus Zambia's single text-only warning: findings from the International Tobacco Control (ITC) Project. Tob Control 2021. doi:10.1136/ tobaccocontrol-2020-056396. [Epub ahead of print: 11 Jun 2021].

36 Pang B, Saleme P, Seydel T, et al. The effectiveness of graphic health warnings on tobacco products: a systematic review on perceived harm and quit intentions. $B M C$ Public Health 2021;21:884.

37 Wellman RJ, O'Loughlin EK, Dugas EN, et al. Reasons for quitting smoking in young adult cigarette smokers. Addict Behav 2018;77:28-33.

38 Kasza KA, Hyland AJ, Borland R, et al. Cross-country comparison of smokers' reasons for thinking about quitting over time: findings from the International Tobacco Control Four Country Survey (ITC-4C), 2002-2015. Tob Control 2017;26:641-8.

39 Hyland A, Li Q, Bauer JE, et al. Predictors of cessation in a cohort of current and former smokers followed over 13 years. Nicotine Tob Res 2004;6 Suppl 3:S363-9.

40 Nordgren P. Renewal of health warnings: lessons learned in Sweden. World Smoking and Health 1993;18:12-14.

41 Naett C, Howie C. The labelling of tobacco products in the European Union. European Bureau for Action on Smoking Prevention, 1993.

42 Joossens L. European community directive on packaging and labelling of tobacco products. World Health Organization, 2004. Available: https://apps.who.int/iris/ bitstream/handle/10665/68645/WHO_NMH_TFI_FTC_04.03.pdf [Accessed 18 Jul 2021].

43 Chitanondh $\mathrm{H}$. Thailand: country report on labelling and packaging. World Health Organization, 2003. Available: https://escholarship.org/uc/item/2cv371pd [Accessed 18 Jul 2021].

44 Sinsuwarn N, Sthapitanonda P. Winning with the public, winning in court: advocacy lessons learnt from $85 \%$ pictorial health warning campaign in Thailand. Tob Control 2019;28:e3-6.

45 Mahood G. Canadian tobacco package warning system. Tob Control 1995;4:10-14

46 Cunningham R. Smoke \& Mirrors: The Canadian Tobacco War, chapter 9. Ottawa: International Development Research Centre, 1996. Available: https://www.idrc.ca/ en/book/smoke-mirrors-canadian-tobacco-war [Accessed 18 Jul 2021].

47 Roemer R. Legislative action to combat the world tobacco epidemic. 2nd ed. Geneva: World Health Organization, 1993. Available: https://apps.who.int/iris/ handle/10665/37823 [Accessed 18 Jul 2021].

48 Tobacco Documentation Centre. Summary country requirements: to display health warnings on cigarette packaging and advertising, 1996. Available: https://www. industrydocuments.ucsf.edu/tobacco/docs/\#id=yqmd0076 [Accessed 18 Jul 2021]

49 Aftab M, Kolben D, Lurie P. International cigarette labelling practices. Tob Control 1999;8:368-72.

50 Canadian Cancer Society. Cigarette Package Health Warnings: International Status Report. 7th ed, 2021. Available: https://www.tobaccofreekids.org/assets/global/pdfs/ en/WL status report en.pdf [Accessed 09 Nov 2021].

51 Brazil. ANVISA Resolution No. 104 of May 31, 2001, 2001. Available: https://www. tobaccocontrollaws.org/files/live/Brazil/Brazil\%20-\%20RDC\%20No.\%20104_2001. pdf [Accessed 02 Oct 2021].

52 International Union Against Cancer, International Union Against Tuberculosis and Lung Disease, World Heart Federation, et al. What would be a fair warning for a lethal product that addicts children, kills when used exactly as intended, and every year causes millions of deaths worldwide? At a minimum, a warning that tells the truth, 2001.
53 Framework Convention Alliance. FCA recommendations: guidelines on article 11 (packaging and labelling of tobacco products), 2007. Available: https://www.fctc. org/wp-content/uploads/2007/06/fca-2007-cop-article11-cop2-recommendationsen.pdf [Accessed 18 Jul 2021].

54 Framework Convention Alliance. Briefing 4: adoption of guidelines for implementation of article 11 (packaging and labelling of tobacco products), 2008. Available: https://www.fctc.org/wp-content/uploads/2008/11/COP-3_policy_ briefing_Article_11_Packaging.pdf [Accessed 18 Jul 2021].

55 Phillip Morris International. Health warning labels, 2010. Available: https://www.pmi. com/principles-and-positions/our-views/regulation [Accessed 06 Nov 2010].

56 World Health Organization. WHO report on the global tobacco epidemic 2021: addressing new and emerging products, 2021. Available: https://www.who.int/ teams/health-promotion/tobacco-control/global-tobacco-report-2021 [Accessed 30 Jul 2021].

57 Bosco F, da Silva HJN, Serekai M. Timor Leste: world's largest graphic health warnings. In: Worldwide news and comment. Tob Control 2018;27:604-5.

58 Tan YL. SEATCA tobacco packaging and labelling index: implementation of article 11 of the who framework convention on tobacco control in ASEAN countries. Bangkok, Thailand: Southeast Asia Tobacco Control Alliance, 2019. Available: https://seatca. org/dmdocuments/SEATCA\%20ARTICLE\%2011\%20INDEX_WEB_F.pdf [Accessed 18 Jul 2021].

59 Canada. Tobacco Products Regulations (Plain and Standardized Appearance), SOR/2019-107, 2019. Available: https://www.tobaccocontrollaws.org/files/live/ Canada/Canada\%20-\%20Plain\%20and\%20Standardized\%20Packaging\% 20Regulations\%20-\%20national.pdf [Accessed 18 Jul 2021].

60 Cunningham R. Canada: warnings with colour pictures required. Tob Control 2000;9:359.

61 Mahood G. Warnings that tell the truth: breaking new ground in Canada. Tob Control 1999;8:356-62.

62 Mahood G. Canada's tobacco package label or warning system: "Telling the Truth" about tobacco product risks, 2003. Available: https://escholarship.org/uc/item/ 3pw4c084 [Accessed 18 Jul 2021].

63 Rothman's, Benson \& Hedges Inc. et al. v. Attorney General of Canada, Quebec Superior Court, 2000. Available: https://www.tobaccocontrollaws.org/litigation/ decisions/ca-20000920-rothmans,-benson--hedges-inc.- [Accessed 18 Jul 2021].

64 Fife R. Disease images take aim at 'national evil': Rock. National Post 20 Jan 2000.

65 Sebrié EM, Blanco A, Glantz SA. Cigarette labeling policies in Latin America and the Caribbean: progress and obstacles. Salud Publica Mex 2010;52 Suppl 2:S233-43.

66 Cunningham R. Germany: World Cup special edition cigarette packs. In: News analysis. Tob Control 2010;19:265.

67 Simpson D. France: packaging is kids stuff. Tob Control 1999;8:362.

68 Simpson D. Hong Kong: Marlboro tries it on (the pack). Tob Control 2002;11:171.

69 Evans AT, Peters E, Shoben AB, et al. Cigarette graphic warning labels are not created equal: they can increase or decrease smokers' quit intentions relative to text-only warnings. Nicotine Tob Res 2017;19:1155-62.

70 Li Y, Yang B, Owusu D, et al. Higher negative emotions in response to cigarette pictorial warning labels predict higher quit intentions among smokers. Tob Control 2020;29:496-501.

71 Cho YJ, Thrasher JF, Swayampakala K, et al. Does reactance against cigarette warning labels matter? Warning label responses and downstream smoking cessation amongst adult smokers in Australia, Canada, Mexico and the United States. PLoS One 2016;11:e0159245.

72 Thrasher JF, Swayampakala K, Borland R, et al. Influences of self-efficacy, response efficacy, and reactance on responses to cigarette health warnings: a longitudinal study of adult smokers in Australia and Canada. Health Commun 2016;31:1517-26.

73 Evans AT, Peters E, Strasser AA, et al. Graphic warning labels elicit affective and thoughtful responses from smokers: results of a randomized clinical trial. PLoS One 2015; 10:e0142879.

74 Hendreys P. Warning labels. Inter-Office correspondence, 2000. Philip Morris international Inc. Available: http://legacy.library.ucsf.edu/tid/gih47c00 [Accessed 18 Jul 2021].

75 Agência Nacional de Vigilância Sanitária (ANVISA) v. Philip Morris Brasil Ind Com. Ltda., no. 2009.02.01.006674-2 Brazil Regional Federal Court of the 2nd Region, 2009. Available: https://www.tobaccocontrollaws.org/litigation/decisions/br20090923-agncia-nacional-de-vigilncia-s [Accessed 18 Jul 2021].

76 Agência Nacional de Vigilância Sanitária (ANVISA) v. Souza Cruz S/A 2009.0.01.004853-3 Brazil Regional Federal Court of the 2nd Region, 2009. Available: https://www.tobaccocontrollaws.org/litigation/decisions/br-20080720agncia-nacional-de-vigilncia-s [Accessed 18 Jul 2021].

77 Blank M-L, Hoek J, Gendall P. Roll-your-own smokers' reactions to cessation-efficacy messaging integrated into tobacco packaging design: a sequential mixed-methods study. Tob Control 2020;30:405-12.

78 Thrasher JF, Swayampakala K, Cummings KM, et al. Cigarette package inserts can promote efficacy beliefs and sustained smoking cessation attempts: a longitudinal assessment of an innovative policy in Canada. Prev Med 2016;88:59-65.

79 Thrasher JF, Islam F, Davis RE, et al. Testing cessation messages for cigarette package inserts: findings from a best/worst discrete choice experiment. Int J Environ Res Public Health 2018;15:282. 
80 Moodie C. Adult smokers' perceptions of cigarette pack inserts promoting cessation: a focus group study. Tob Control 2018;27:72-7.

81 Thrasher JF, Osman A, Abad-Vivero EN, et al. The use of cigarette package inserts to supplement pictorial health warnings: an evaluation of the Canadian policy. Nicotine Tob Res 2015;17:870-5

82 Willemsen MC, Simons C, Zeeman G. Impact of the new EU health warnings on the Dutch quit line. Tob Control 2002;11:381-2.

83 Li J, Grigg M. New Zealand: new graphic warnings encourage registrations with the Quitline. Tob Control 2009;18:72.

84 Young JM, Stacey I, Dobbins TA, et al. Association between tobacco plain packaging and Quitline calls: a population-based, interrupted time-series analysis. Med J Aust 2014:200:29-32.

85 Baskerville NB, Brown KS, Nguyen NC, et al. Impact of Canadian tobacco packaging policy on use of a toll-free quit-smoking line: an interrupted time-series analysis. CMAJ Open 2016:4:E59-65.

86 Baskerville NB, Hayward L, Brown KS, et al. Impact of Canadian tobacco packaging policy on Quitline reach and reach equity. Prev Med 2015;81:243-50.

87 Miller CL, Hill DJ, Quester PG, et al. Impact on the Australian Quitline of new graphic cigarette pack warnings including the Quitline number. Tob Control 2009;18:235-7.

88 Thrasher JF, Osman A, Moodie C, et al. Promoting cessation resources through cigarette package warning labels: a longitudinal survey with adult smokers in Canada, Australia and Mexico. Tob Control 2015;24:e23-31.

89 Kumar R, Saroj SK, Kumar M. Tobacco Quitline toll-free number on tobacco packets in India: an analysis on outcome. Monaldi Arch Chest Dis 2021;91:1612.

90 European Community. Council Directive of 13 November 1989 on the approximation of the laws, regulations and administrative provisions of the Member States concerning the labelling of tobacco products. (89/662/EEC), 1989. Available: https:// op.europa.eu/en/publication-detail/-/publication/c1508ccd-3f7a-4859-9529c4d2f1c8d457/language-en [Accessed 18 Jul 2021]

91 Cunningham R. Djibouti: quit \& save money, pack warnings urge. Tob Control 2010;19:94.

92 Australia. Trade Practices (Consumer Product Safety Standard) (Reduced Fire Risk Cigarettes) Regulations 2008, 2008. Available: https://www.tobaccocontrollaws. org/files/live/Australia/Australia\%20-\%20Reduced\%20Fire\%20Risk\%20Cigs\% 20Regs\%202008\%20-\%20national.pdf [Accessed 2 Oct 2021].

93 European Union. Commission implementing regulation (EU) 2020/2151 of 17 December 2020 laying down rules on harmonised marking specifications on singleuse plastic products listed in part D of the Annex to directive (EU) 2019/904 of the European Parliament and of the Council on the reduction of the impact of certain plastic products on the environment, 2020. Available: https://eur-lex.europa.eu/eli/ reg impl/2020/2151 [Accessed 18 Jul 2021].

94 Hitchman SC, Driezen P, Logel C, et al. Changes in effectiveness of cigarette health warnings over time in Canada and the United States, 2002-2011. Nicotine Tob Res 2014; 16:536-43.

95 Li L, Borland $\mathrm{R}$, Yong $\mathrm{H}$, et al. Longer term impact of cigarette package warnings in Australia compared with the United Kingdom and Canada. Health Educ Res 2015;30:67-80.

96 Hammond D. Canada: a new angle on packs. Tob Control 2006:15:150

97 Crespi $\mathrm{E}$, lacobelli $\mathrm{M}$, Welding $\mathrm{K}$, et al. Industry manipulation of pictorial health warning labels in Pakistan. Tob Control 2021. doi:10.1136/ tobaccocontrol-2020-056433. [Epub ahead of print: 16 Apr 2021].

98 Tan YL. Implementing pictorial health warnings in Malaysia: challenges and lessons learned. Bangkok, Thailand: Southeast Asia Tobacco Control Alliance, 2019. Available: https://seatca.org/dmdocuments/Implementing\%20PHW\%20in\% 20Malaysia\%202010.pdf [Accessed 18 Jul 2021].

99 Cohen JE, Brown J, Washington C, et al. Do cigarette health warning labels comply with requirements: a 14-country study. Prev Med 2016:93:128-34.

100 Framework Convention Alliance. Tobacco warning labels. Factsheet \# 72005.

101 Campaign for Tobacco-Free Kids. Pictorial health warning labels: countering tobacco industry arguments, 2017. Available: https://www.tobaccofreekids.org/assets/global/ pdfs/en/WL_industry_arguments_en.pdf [Accessed 18 Jul 2021].

102 JTI-Macdonald Corp. Response to Health Canada's consultation on the proposed Tobacco Products Labelling (Cigarettes and Little Cigars) Regulations 2011.

103 Australia - certain measures concerning trademarks, geographical indications and other plain packaging requirements applicable to tobacco products and packaging. World Trade Organization Appellate Body, WT/DS435/AB/R and WT/DS441/AB/R, 2020. Available: https://www.tobaccocontrollaws.org/litigation/decisions/au20200609-wto-issues-final-ruling-uphold [Accessed 18 Jul 2021].

104 The Queen v. Secretary of State for Health, ex parte Gallaher Ltd., et al. Case C-11/92, European Court of Justice (Fifth Chamber), 1993. Available: https://www. tobaccocontrollaws.org/litigation/decisions/gb-19930622-the-queen-v.-secretary-ofstat [Accessed 18 Jul 2021].

105 Tobacco Company A. v. Federal Republic of Germany. BVerfGE 95, 173, Federal Constitutional Court of Germany, 1997. Available: https://www.tobaccocontrollaws. org/litigation/decisions/de-19970122-tobacco-company-a,-et-al.-v.-f [Accessed 18 Jul 2021].

106 Philip Morris Brands SARL, Philip Morris Ltd, British American Tobacco UK Ltd v. The Secretary of State for Health. Case C-547/14, Court of Justice of the European
Union, 2016. Available: https://www.tobaccocontrollaws.org/files/live/litigation/ 2457/EU_R\%20\%28on\%20the\%20Application\%20of\%29\%20Phil.pdf [Accessed 18 Jul 2021].

107 The Queen v. Secretary of State for Health, ex parte British American Tobacco (Investments) Ltd., et al., case C-491/01, Court of Justice of the European Union, 2002. Available: https://www.tobaccocontrollaws.org/litigation/decisions/gb20021210-the-queen-v.-secretary-of-stat [Accessed 18 Jul 2021].

108 Campaign for Tobacco-Free Kids. Tobacco industry loses landmark court rulings in India and EU, upholding graphic tobacco warnings (and other health measures in EU), 2016. Available: https://www.tobaccofreekids.org/press-releases/2016_05_04_ india [Accessed 18 Jul 2018].

109 Philippine Tobacco Institute, Inc. v. Secretary of Health, et al. G.R. No. 146343, Philippines Supreme Court, Manila, Second Division, 2001. Available: https://www. tobaccocontrollaws.org/litigation/decisions/ph-20010620-philippine-tobaccoinstitute,- [Accessed 18 Jul 2021].

110 Philippine Tobacco Institute, Inc. v. Secretary of Health, CA-G.R. CV. No. 49376, Philippines Court of Appeals, Manila, Sixth Division, 2000. Available: https://www. tobaccocontrollaws.org/litigation/decisions/ph-20000210-philippine-tobaccoinstitute,- [Accessed 18 Jul 2021].

111 Canada (Attorney General) v. JTI-Macdonald Corp., Rothmans, Benson \& Hedges Inc., Imperial Tobacco Canada Ltd., Supreme Court of Canada, 2007. Available: https://www.tobaccocontrollaws.org/files/live/litigation/468/CA_Canada\%20\% 28Attorney\%20General\%29\%20v.\%20J.pdf [Accessed 18 Jul 2021].

112 JTI-MacDonald Corporation, Rothmans, Benson \& Hedges Inc., Imperial Tobacco Canada Ltd. v. Canada (Attorney General), Quebec Court of Appeal, 2005. Available: https://www.canlii.org/en/qc/qcca/doc/2005/2005qcca726/2005qcca726.htm [Accessed 18 Jul 2021]

113 J.T.I. MacDonald Corporation, Rothmans, Benson \& Hedges Inc., Imperial Tobacco Canada Ltd. v. Canada (Attorney General), Quebec Superior Court, 2002. Available: https://www.canlii.org/en/qc/qccs/doc/2002/2002canlii63662/2002canlii63662.html [Accessed 18 Jul 2021].

114 Philip Morris Brands Sarl, Philip Morris Products S.A., Abal Hermanos S.A. v. Oriental Republic of Uruguay, ICSID case No. ARB/10/7, International Centre for Settlement of Investment Disputes, Washington, D.C., 2016. Available: https://www. tobaccocontrollaws.org/files/live/litigation/2512/UY_Philip\%20Morris\%20S\%C3\% 80RL\%20v.\%20Uruguay.pdf [Accessed 18 Jul 2021].

115 Abal Hermanos, S.A. v. Uruguay. Judgment No. 1713, Supreme Court of Justice, 2010. Available: https://www.tobaccocontrollaws.org/files/live/litigation/1248/UY_ Abal\%20Hermanos\%2C\%20S.A.\%20v.\%20Uruguay.pdf [Accessed 18 Jul 2021].

116 Application for Judicial Review of Elucidation of Article 114 of Law No. 36 of 2009 About Health, Ruling in Case 34 - PUU-VIII/2010, Constitutional Court of the Republic of Indonesia, 2011. Available: https://www.tobaccocontrollaws.org/ litigation/decisions/id-20111018-judicial-review-of-articles-11 [Accessed 18 Jul 20211.

117 Application for Judicial Review of Elucidation of Article 114 of Law No. 36 of 2009 About Health, Ruling in Case 19 - PUU-VIII/2010, Constitutional Court of the Republic of Indonesia, 2011. Available: https://www.tobaccocontrollaws.org/ litigation/decisions/id-201111101-judicial-review-of-article-114 [Accessed 18 Jul 2021]

118 Bhatta DN, Crosbie E, Bialous SA, et al. Defending comprehensive tobacco control policy implementation in Nepal from tobacco industry interference (2011-2018). Nicotine Tob Res 2020;22:2203-12

119 JT International Company (Thailand), Limited, JT International SA v. Minister of Public Health, Ministry of Public Health. Supreme Administrative Court, Order No. 269/2557, 2014. Available: https://www.tobaccocontrollaws.org/litigation/decisions/ th-00000000-jti-international-thailand-v.- [Accessed 18 Jul 2021]

120 In the matter of a reference in terms of Article 122(1)(b) of the Constitution "An Act to Amend the National Authority on Tobacco and Alcohol Act, No.27 of 2006". S.C. (SD) No. 2/2015, Sri Lanka Supreme Court, 2015. Available: https://www. tobaccocontrollaws.org/files/live/litigation/2229/LK_In\%20the\%20matter\%20of\% 20Article\%20122\%281.pdf [Accessed 18 Jul 2021].

121 British American Tobacco Kenya Ltd. v. Cabinet Secretary for the Ministry of Health Petition No. 143 of 2015, High Court of Kenya at Nairobi, Constitutional and Human Rights Division, 2016. Available: https://www.tobaccocontrollaws.org/files/live/ litigation/2643/KE_British\%20American\%20Tobacco\%20Kenya.pdf [Accessed 18 Jul 2021]

122 British American Tobacco Ltd v. Cabinet Secretary for the Ministry of Health, et al. Civil appeal No. 112 of 2016, Court of Appeal at Nairobi, 2017. Available: https:// www.tobaccocontrollaws.org/files/live/litigation/2521/KE_British\%20American\% 20Tobacco\%20Ltd\%20v.pdf [Accessed 18 Jul 2021].

123 British American Tobacco Kenya, PLC v. Cabinet Secretary for the Ministry of Health, et al. Supreme Court of Kenya, Petition No. 5 of 2017, 2019. Available: https:// www.tobaccocontrollaws.org/files/live/litigation/2708/KE_British\%20American\% 20Tobacco\%20Kenya.pdf [Accessed 18 Jul 2021].

124 Karnataka Beedi Industry Association and Anr. v. Union of India and Anr. Special leave Petition (C) Nos. 10119-10121, Supreme Court of India, 2016. Available: https://www.tobaccocontrollaws.org/litigation/decisions/in-20160504-karnatakabeedi-industry-assoc [Accessed 18 Jul 2021]. 
125 Health for Millions Trust v. Union of India. Petition for special leave to appeal (C) No. 37348 of 2017, Supreme Court of India, 2018. Available: https://www. tobaccocontrollaws.org/litigation/decisions/in-20180108-health-for-millions-trustv.-u [Accessed 18 Jul 2021].

126 British American Tobacco Limited v. Attorney General and Centre for Health Human Rights and Development. Constitutional petition No. 46 of 2016, Constitutional Court of Uganda at Kampala, 2019. Available: https://www.tobaccocontrollaws.org/ litigation/decisions/ug-20190528-bat-uganda-Itd-v.-attorney-gen [Accessed 18 Jul 2021].

127 Discount Tobacco City \& Lottery, Inc. v. United States. 674 F.3d 509, US Court of Appeals for the Sixth Circuit, 2012. Available: https://www.tobaccocontrollaws.org/ litigation/decisions/us-20120319-discount-tobacco-city--lottery [Accessed $18 \mathrm{Jul}$ 2021].

128 R.J. Reynolds Tobacco Co. v. United States Food \& Drug Administration. 845 F.Supp.2d 266, US Court of Appeals for the District of Columbia Circuit, 2012 Available: https://www.tobaccocontrollaws.org/litigation/decisions/us-20120824-r. j.-reynolds-v.-food--drug-ad [Accessed 18 Jul 2021].

129 Tobacco Control Legal Consortium. Cigarette graphic warnings and the divided federal courts, 2015. Available: https://www.publichealthlawcenter.org/sites/default/ files/resources/Tobacco-Control-Legal-Consortium-Cigarette-Graphic-Warnings-andthe-Divided-Federal-Courts.pdf [Accessed 18 Jul 2021].

130 Unión Tabacalera del Paraguay, Tabacalera del Este S.A., Mercury Tabacos S.A v. Paraguay. Judgment No. 916, Supreme Court of Justice, 2009. Available: https:// www.tobaccocontrollaws.org/litigation/decisions/py-20091228-unin-tabacalera-delparaguay,- [Accessed 28 Jul 2021].

131 Telengtan Brothers \& Sons, Inc. v. The Department of Health. Civil Case No. 10-0277, Philippines National Capital Judicial Region Regional Trial Court, branch 196, Paranque City, 2010. Available: https://www.tobaccocontrollaws.org/files/ live/litigation/839/PH_Telengtan\%20Brothers $\% 20 \% 26 \% 20$ Sons $\% 2$ C $\% 20$ Inc.pdf [Accessed 18 Jul 2021].

132 B.A.T. v. Tobacco and Alcohol Markets Regulatory Authority. 2009/5805, Thirteenth Court Circuit, Turkey, 2009. Available: https://www.tobaccocontrollaws.org/litigation/ decisions/tr-20091201-british-american-tobacco-v.-to [Accessed 18 Jul 2021].

133 Hammond D. FCTC article 11 fact sheet. Emission and constituent labelling. International Union Against Tuberculosis and Lung Disease and University of Waterloo, 2008. Available: https://tobaccolabels.s3.ca-central-1.amazonaws.com/ uploads/2013/12/Article_11_Fact_Sheet_-_Emissions_Constituents_2008.pdf [Accessed 18 Jul 2021].

134 Campaign for Tobacco-Free Kids. Tobacco control laws emission yields data, 2021.

135 Brazil. ANVISA Resolution No. 46 of March 28, 2001, 2001. Available: https://www. tobaccocontrollaws.org/files/live/Brazil/Brazil\%20-\%20RDC\%20No.\%2046.pdf [Accessed 02 Oct 2021].

136 Calvacante TM. Labelling and packaging in Brazil. World Health Organization, 2003. Available: https://escholarship.org/uc/item/5032b2bb [Accessed 02 Oct 2021].

137 Conference of the Parties to the WHO Framework Convention on Tobacco Control. Guidelines for Implementation of Article 13 of the WHO Framework Convention on Tobacco Control (Tobacco Advertising, Promotion and Sponsorship), 2008. Available: https://fctc.who.int/docs/librariesprovider12/default-document-library/ who-fctc-article-13.pdf?sfvrsn=345fb387_1\&download=true [Accessed $18 \mathrm{Jul}$ 2021].

138 European Union. Directive 2014/40/EU of the European Parliament and of the Council of 3 April 2014 on the approximation of the laws, regulations and administrative provisions of the Member States concerning the manufacture, presentation and sale of tobacco and related products and repealing Directive 2001/37/EC, 2014. Available: https://www.tobaccocontrollaws.org/files/live/ European\%20Union/European\%20Union\%20-\%20TPD\%202014\%20-\% 20national.pdf [Accessed 18 Jul 2021].

139 Canada. Promotion of Tobacco Products and Accessories Regulations (Prohibited Terms), SOR/2011-178, 2011. Available: https://www.tobaccocontrollaws.org/files/ live/Canada/Canada\%20-\%20Prohibited\%20Terms\%20Regs\%20-\%20national.pdf [Accessed 18 Jul 2021].

140 Israel. Restriction of Advertising and Marketing of Tobacco Products Law (Amendment No. 7), 5779-2019, 2019. Available: https://www.tobaccocontrollaws. org/files/live/lsrael/Israel\%20-\%20Amdt.\%207\%20to\%20Marketing\%20Law.pdf [Accessed 2 Oct 2021].

141 Sebrie E. Mexico: backroom deal blunts health warnings. Tob Control 2006;15:348-9.

142 United States v. Philip Morris USA Inc., US District Court for the District of Columbia, 2018. Available: https://www.tobaccofreekids.org/assets/content/ press_office/2018/2018_05_01_correctivestatements.pdf [Accessed 18 Jul 2021].

143 American Cancer Society, American Heart Association, American Lung Association, et al. Tobacco companies ordered to place statements about products' dangers on websites and cigarette packs, 2018. Available: https://www.tobaccofreekids.org/ assets/content/press_office/2018/2018_05_01_correctivestatements.pdf [Accessed 18 Jul 2021].

144 Moodie C, Hoek J, Hammond D. Plain tobacco packaging: progress, challenges, learning and opportunities. Tob Control 2022;31:262-70.
145 Mercincavage M, Albelda B, Mays D, et al. Shedding 'light' on cigarette pack design: colour differences in product perceptions, use and exposure following the US descriptor ban. Tob Control 2022;31:19-24.

146 Borland R, Fong GT, Yong H-H, et al. What happened to smokers' beliefs about light cigarettes when "light/mild" brand descriptors were banned in the UK? Findings from the International Tobacco Control (ITC) Four Country Survey. Tob Control 2008; 17:256-62.

147 Falcone M, Bansal-Travers M, Sanborn PM, et al. Awareness of FDA-mandated cigarette packaging changes among smokers of 'light' cigarettes. Health Educ Res 2015:30:81-6

148 Connolly GN, Alpert HR. Has the tobacco industry evaded the FDA's ban on 'Light' cigarette descriptors? Tob Control 2014;23:140-5.

149 Hammond D, Parkinson C. The impact of cigarette package design on perceptions of risk. J Public Health 2009;31:345-53.

150 Crosbie E, Sosa P, Glantz SA. Defending strong tobacco packaging and labelling regulations in Uruguay: transnational tobacco control network versus Philip Morris International. Tob Control 2018:27:185-94.

151 Informa Market Research Co Ltd. Pilot test on-product warnings, Toronto (prepared for Canadian Cancer Society), 2006

152 Hoek J, Robertson C. How do young adult female smokers interpret dissuasive cigarette sticks? J Soc Mark 2015;5:21-39.

153 Hassan LM, Shiu E. No place to hide: two pilot studies assessing the effectiveness of adding a health warning to the cigarette stick. Tob Control 2015;24:e3-5.

154 Hoek J, Gendall P, Eckert C, et al. Dissuasive cigarette sticks: the next step in standardised ('plain') packaging? Tob Control 2016;25:699-705.

155 Drovandi A, Teague P-A, Glass B, et al. A systematic review of smoker and non-smoker perceptions of visually unappealing cigarette sticks. Tob Induc Dis 2018; 16:02.

156 Drovandi A, Teague P-A, Glass B, et al. Australian school student perceptions of effective anti-tobacco health warnings. Front Public Health 2018;6:297.

157 Moodie C. Warnings on every cigarette: extending health messaging to the consumption experience. CMAJ 2018;190:E1271-2.

158 Lund I, Scheffels J. Adolescent perceptions of dissuasive sticks: a web survey among 16-20 year olds in Norway. BMC Public Health 2018;18:974.

159 Moodie C, Gendall P, Hoek J, et al. The response of young adult smokers and nonsmokers in the United Kingdom to dissuasive cigarettes: an online survey. Nicotine Tob Res 2019;21:227-33.

160 Gallopel-Morvan K, Droulers O, Pantin-Sohier G. Dissuasive cigarettes: which cues are the most effective at deterring young people from smoking? Public Health 2019;174:22-30

161 Drovandi A, Teague P-A, Glass B, et al. A systematic review of the perceptions of adolescents on graphic health warnings and plain packaging of cigarettes. Syst Rev 2019;8:25.

162 Mitchell D, Critchlow N, Moodie C, et al. Reactions to, and trial intentions for, three dissuasive cigarette designs: a cross-sectional survey of adolescents in Scotland. Tob Control 2021:30:623-9.

163 Health Canada. New health-related labelling for tobacco products: document for consultation, 2018. Available: https://www.canada.ca/content/dam/hc-sc documents/programs/consultation-tobacco-labelling/27-18-2150-TobaccoConsultation-Labels-EN-12.pdf [Accessed 18 Jul 2021].

164 Health Canada. New health-related labelling for tobacco products: consultation summary, 2019. Available: https://www.canada.ca/content/dam/hc-sc/documents/ services/publications/healthy-living/consultation-new-labelling-tobacco-what-weheard/consultation-new-labelling-tobacco-what-we-heard.pdf [Accessed 18 Jul 2021].

165 Cunningham R. Canada: consultation launched for warnings directly on cigarettes. In: Worldwide news and comment. Tob Control 2019;28:4.

166 UK House of Lords, HL Bill 29, Cigarette Stick Health Warnings Bill, first reading, 14 Jun 2021. Available: https://bills.parliament.uk/bills/2889 [Accessed 18 Jul 2021].

167 Singapore Customs. Every cigarette stick to bear "SDPC" marking from 1 January 2009, 2008. Singapore customs news release. Available: https://www.customs.gov. sg/news-and-media/media-releases/2008-09-10-Media-Release-ciggmarking.pdf [Accessed 18 Jul 2021].

168 Singapore Customs. Revised 'SDPC' mark for cigarettes sold in Singapore from next March, 2012. Available: https://www.customs.gov.sg/news-and-media/mediareleases/2012-11-29-Media-Release.pdf [Accessed 18 Jul 2021].

169 Mehrotra R, Yadav A, Sinha DN, et al. Smokeless tobacco control in 180 countries across the globe: call to action for full implementation of WHO FCTC measures. Lancet Oncol 2019;20:e208-17.

170 Jarrett T, Blosnich J, Tworek C, et al. Hookah use among U.S. college students: results from the National College Health Assessment II. Nicotine Tob Res 2012;14:1145-53.

171 Cornacchione J, Wagoner KG, Wiseman KD, et al. Adolescent and young adult perceptions of hookah and little cigars/cigarillos: implications for risk messages. J Health Commun 2016:21:818-25.

172 Mostafa A, Mohammed HT, Hussein WM, et al. Plain packaging of waterpipe tobacco? A qualitative analysis exploring waterpipe smokers' and non-smokers' responses to enhanced versus existing pictorial health warnings in Egypt. BMJ Open 2018;8:e023496. 
173 Nakkash R, Tleis M, Chehab S, et al. Novel insights into young adults' perceived effectiveness of waterpipe tobacco-specific pictorial health warning labels in Lebanon: implications for tobacco control policy. Int J Environ Res Public Health 2021;18:7189.

174 Mostafa A, Mohammed HT, Hussein WM, et al. Would placing pictorial health warnings on waterpipe devices reduce waterpipe tobacco smoking? A qualitative exploration of Egyptian waterpipe smokers' and non-smokers' responses. Tob Control 2019:28:475-8

175 Maziak W, Ben Taleb Z, Ebrahimi Kalan M, et al. Pictorial health warning labels on the waterpipe device are effective in reducing smoking satisfaction, puffing behaviour and exposure to CO: first evidence from a crossover clinical laboratory study. Tob Control 2019;28:e37-42.

176 Turkey. Communiqué regarding the procedures and principles of health warnings to be placed on waterpipe bottles. Official Gazette, 2013. Available: https://www. resmigazete.gov.tr/eskiler/2013/05/20130528-15.htm [Accessed 18 Jul 2021].

177 Turkey. Communiqué regarding the procedures and principles of health warnings to be placed on waterpipe bottles. Official Gazette, 2020. Official Gazette. Available: https://www.resmigazete.gov.tr/eskiler/2020/02/20200219-6.htm [Accessed 18 Jul 2021].

178 Department of Tobacco and Alcohol, Tobacco and Tobacco Products Department. Turkey Ministry of alcohol and forestry A.7, A.7.2. Available: https://www. tarimorman.gov.tr/TADB/Menu/22/Tutun-Ve-Tutun-Mamulleri-Daire-Baskanligi [Accessed 18 Jul 2021].

179 Nigeria. National Tobacco Control Regulations, 2019, SI. No. 46, 2019. Available: https://www.tobaccocontrollaws.org/files/live/Nigeria/Nigeria\%20-\%202019\% 20Regulations\%20-\%20national.pdf [Accessed 20 Dec 2019].

180 WHO Framework Convention on Tobacco Control Secretariat. WHO FCTC health warnings database, 2020. Available: http://www.who.int/tobacco/healthwarningsda tabase/en/index.html

181 Campaign for Tobacco-Free Kids. Tobacco control laws. Available: www. tobaccocontrollaws.org [Accessed 18 Jul 2021].
182 Campaign for Tobacco-Free Kids. Warning labels. Available: https://www. tobaccofreekids.org/global-issues/advocacy-resources/warning-labels [Accessed 18 Jul 2021].

183 Tobacco labelling resource centre. Available: https://www.tobaccolabels.ca/ [Accessed 18 Jul 2021].

184 Institute for Tobacco Control, Johns Hopkins Bloomberg School of Public Health. Tobacco packs surveillance system. Available: https://www.globaltobaccocontrol.org/ tpackss/ [Accessed 18 Jul 2021]

185 Campaign for Tobacco-Free Kids. Global legal center. Available: https://www. tobaccofreekids.org/what-we-do/global/legal [Accessed 18 Jul 2021].

186 Allen E. Sense and nonsense of warning labels. Tobacco Journal International OctNov 2011.

187 Campaign for Tobacco-Free Kids. Showing the truth, saving lives. Available: https:// www.tobaccofreekids.org/what-we-do/global/warning-labels [Accessed 18 Jul 2021].

188 Drope J, Schluger N, Cahn Z. The tobacco atlas. 6th ed. Atlanta: American Cance Society and Vital Strategies, 2018. Available: https://files.tobaccoatlas.org/wpcontent/uploads/2018/03/TobaccoAtlas_6thEdition_LoRes.pdf [Accessed 18 Jul 2021].

189 WHO Framework Convention on Tobacco Control Secretariat. WHO FCTC implementation database. Available: https://untobaccocontrol.org/impldb/ [Accessed 18 Jul 2021].

190 Simpson D. Poland's world-leading health warnings. Tob Control 1998;7:277.

191 Borland R, Hill D. The path to Australia's tobacco health warnings. Addiction 1997:92:1151-8.

192 Cunningham R. Best practices in implementation of article 11 of the WHO FCTC case study: Mauritius, 2013. WHO Framework Convention on Tobacco Control Secretariat. Available: https://www.who.int/fctc/publications/final_mauritius_art11_national_1. pdf [Accessed 18 Jul 2021]. 